CEB Working Paper

\title{
A resource-rich neighbor is a misfortune: The spatial distribution of the resource curse in Brazil
}

\author{
Phoebe W. Ishak and Pierre-Guillaume Méon
}

We study the spatial distribution of the effect of oil and gas revenues on Brazilian municipalities, using variations in the international prices of oil and gas to establish causality. Oil and gas revenues increase economic activity, measured by night-time light emissions, in oil-producing municipalities but impose negative spill-overs on neighbouring municipalities. Spill-overs dominate beyond $150 \mathrm{~km}$ from oil activities and compensate direct effects in micro-regions. In oil municipalities, oil and gas revenues increase royalties, population, local real prices, crime, and real wages, essentially in manufacturing and services. Spillovers are negative on wages and prices and positive on royalties and crime.

Keywords: 011, 013, Q32.

JEL Classifications: Natural resources curse, oil, spill-over effects, Night-time lights, Brazil.

\author{
CEB Working Paper N²0/001 \\ January 2020
}




\title{
A resource-rich neighbor is a misfortune: The spatial distribution of the resource curse in Brazil
}

January 2020

\author{
Phoebe W. Ishak ${ }^{1}$ \\ Universität Hamburg \\ Faculty of Business, Economics and Social \\ Sciences \\ Volkswirtschaftslehre \\ Von-Melle-Park5 \\ 20146 Hamburg \\ phone: + $494042838-9769$
}

\section{Pierre-Guillaume Méon}

Université libre de Bruxelles (ULB)

Centre Emile Bernheim

CP-114/03

avenue F.D. Roosevelt, 50

1050 Bruxelles, Belgium

phone: +32-2-650-65-99

e-mail:pgmeon@ulb.ac.be

e-mail: phoebe.wasfy.ishak@uni-hamburg.de

\begin{abstract}
We study the spatial distribution of the effect of oil and gas revenues on Brazilian municipalities, using variations in the international prices of oil and gas to establish causality. Oil and gas revenues increase economic activity, measured by night-time light emissions, in oil-producing municipalities but impose negative spill-overs on neighbouring municipalities. Spill-overs dominate beyond $150 \mathrm{~km}$ from oil activities and compensate direct effects in micro-regions. In oil municipalities, oil and gas revenues increase royalties, population, local real prices, crime, and real wages, essentially in manufacturing and services. Spillovers are negative on wages and pricesand positive on royalties and crime.
\end{abstract}

Keywords: Natural resources curse, oil, spill-over effects, Night-time lights, Brazil.

JEL codes: O11, O13, Q32.

Acknowledgements: We thank Hannes Mueller, Stefan Voigt, Jerg Gutmann and Olaf Posch for their helpful comments. Parts of the paper were written while Phoebe W. Ishak was visiting the Economics Department at Universitat Autònoma de Barcelona.

\footnotetext{
${ }^{1}$ Corresponding author.
} 


\section{Introduction}

The existence of the natural resource curse as a firmly established stylized fact has tarnished. At the country level, the evidence is mixed. While early work by Sachs and Warner $(1995,2001)$ or Auty (2001) reported that growth was lower in resource-rich countries, Alexeev and Conrad (2009) provided evidence that the curse depended on the period of observation and on the definition of economic performance. Specifically, when performance is measured by the level of output per capita instead of its growth, which allows to take into account the total effect of natural resources, the curse in fact appears to be a blessing. Cotet and Tsui (2013) confirmed the finding. Moreover, studies using within-country data consistently report evidence that natural resource abundance or booms in the price of natural resources improve the economic performance of the areas that produce the natural resources. The finding applies to both developed and developing countries and various periods. In the US, for instance, Black et al. (2005) and Allcot and Keniston (2018) observed that the 1970s oil-price boom increased production in oil-, gas-, and coal-producing counties, while Michaels (2011) reported that counties better endowed with oil experienced a faster growth of employment in both mining and manufacturing. By the same token, Aragón and Rud (2013) observed that the discovery and exploitation of a goldmine in Peru increased local incomes. Gradstein and Klemp (2016) and Mamo et al. (2018) report that natural resources increased economic performance proxied by night-time light emissions, respectively for oil in Brazil and mining in Africa. Natural resources therefore appear to be a blessing for the subnational areas that produce them. Does it mean that natural resources are a curse for no one?

In this paper, we argue to the contrary. The spatial dimension of the effect of natural resources is key, because the benefits and costs of resource windfalls are unevenly distributed across space. Specifically, municipalities that produce oil likely benefit from the activity and revenues that natural resources generate and likely grow. However, to do so, they draw on resources from other municipalities, thereby imposing negative externalities. They may also impose costs in the guise of crime, corruption, or conflict. The balance between the benefits and the costs of natural resources is therefore likely spatially uneven, with positive effects dominating in the vicinity of resource-producing municipalities then fading away as distance grows. As a result, some non-resource-producing municipalities may suffer from resource windfalls. Moreover, the net aggregate effect may be either insignificant or negative despite the direct effect being positive. Consequently, the effect of natural resources measured at the local level maybe positive while it may turn out insignificant or even negative when observed at higher levels of aggregation, such as regions or countries. That may explain why subnational studies report unmitigated positive effects while the findings of cross-country studies are contradictory.

We test that hypothesis using data on oil and gas revenues in Brazilian municipalities. Brazil is an appealing case for several reasons. First, it is the tenth larger oil producer in the world without being an OPEC member. This implies that while oil matters to Brazil, its influence on world prices is limited. Furthermore, there is an official distinction between oil-producing and non-oil producing 
municipalities. ${ }^{2}$ Brazil has designed a system whereby oil and gas revenues automatically accrue to oilproducing municipalities and states in the form of royalties. Municipalities are therefore the natural unit of observation of the effect of oil on performance. ${ }^{3}$ Finally, the features of oil production in Brazil allows us to identify the causal impact of oil and gas revenues on Brazilian municipalities. We do so by exploiting the fact that fluctuations in oil and gas prices are exogenous to whatever happens in each municipality. We can therefore compute an exogenous component of oil and gas revenues by multiplying the initial level of production of each municipality by the prices of oil and gas. As those prices are determined on global markets, the result of that product can safely be considered exogenous to Brazilian municipalities.

To study the geographic dimension and the spill-over effects of oil, we follow Mamo et al. (2019) and chiefly estimate a spatial Durbin model (SDM). ${ }^{4}$ That model relates the performance of a municipality to its own oil revenues and to those of adjacent municipalities. It therefore allows to determine the sign and the magnitude of the effects of oil revenues on both oil-producing and non-oil producing municipalities. As a complement, we also model spillovers using distance measures to the nearest oil municipality to more precisely study how spillovers vary as one moves away from oilproducing municipalities. We also look at wider units of observation, specifically micro- and macroadministrative units. By construction, those units include both oil-producing and non-oil-producing municipalities. By studying the effect of oil on those aggregated units, one de facto observes the sum of the direct effect of oil and its spillovers.

Our workhorse measure of economic performance is night-time light emissions, which has been used as a proxy for GDP at the sub-national level, for instance by Henderson et al. (2012), Hodler and Raschky (2014), Mamo et al. (2018), and, specifically on Brazil, by Gradstein and Klemp (2017). We, however, complement that baseline measure by a series of variables that are measured at the municipality level, to investigate the channels of transmission of oil to economic performance.

Our paper chiefly contributes to the literature that investigates the effect of natural resources on economic performance at the subnational level (e.g., Black et al., 2005, Allcot and Keniston, 2018, Michaels, 2011, Gradstein and Klemp, 2016). It also contributes to the literature that investigates the spatial spillovers of natural resources, be it on economic performance (Aragón and Rud, 2013, Mamo etal., 2019), or gender relations (Kotsadam and Tolonen, 2016). We in particular complement the papers of Mamo et al. (2019) and Gradstein and Klemp (2016). While Mamo et al. (2019) focus on mining in Sub-Saharan Africa, we consider Brazil, which allowsus to consider observations that are institutionally homogeneous and to take advantage of the specificities of the distribution of oil revenues among Brazilian municipalities. We share our focus on oil and light emissions in Brazil with Gradstein and Klemp (2016) but depart from their analysis insofar as we work at the level of individual municipalities

\footnotetext{
${ }^{2}$ In Brazil, gas production is a by-product of oil production. For conciseness' sake, we therefore refer to oilproduction or oil-producing municipa lities even though municipa lities may produce both oil and gas.

${ }^{3}$ See Caselli and Michaels (2013) for an overview of oil production and oil-producing municipa lities in Brazil.

${ }^{4}$ See also Harariand La Ferrara (2018) for a similar procedure.
} 
instead of reconstructed cells. Second, we consider the revenues of both oil and gas, as opposed to oil only. Although gas was essentially a byproduct of oil production and the Brazilian oil production barely covered Brazilian consumption over most of our period of study, it still contributed to the revenue windfall from hydrocarbon production. Third, and more importantly, our main focus is on the spatial spillovers between municipalities of oil and gas revenues. The fact that oil and gas revenues essentially accrue to oil-producing municipalities makes municipalities the natural level of analysis. Moreover, we use several techniques designed to capture those spillovers and study how they change across space. Third, our explanatory variable is the product of current oil and gas prices and initial oil and gas productions, which is in line with the rule used to share oil and gas revenues among Brazilian municipalities, while Gradstein and Klemp (2016) consider the product of oil price and distance to the nearest oil field. Our explanatory variable can therefore better approximate oil and gas revenues in a municipality, which are a function of both oil and gas prices and quantities. Finally, working at the level of municipalities allows us to consider a series of dependent variables in addition to light emissions and thereby study the channels of transmission of spillovers. We find that oil and gas revenues have a positive direct effect on economic activity in oil municipalities, with a 10 percent increase in revenues boosting economic activity by about 1.4 percent in oil producing municipalities, on average. In contrast, non-oil municipalities are shown to suffer negative spillovers from oil and gas revenues, with the spillover effect being nearly of the samemagnitude as the direct impact. Further, by employing distanceweighted measures of oil and gas revenues, we find negative spillovers to become stronger relative to direct effects, the further the municipality from oil production locations. According to our estimates, the negative significant spillovers starts to dominate in municipalities located at around $150 \mathrm{~km}$ from oil activities. We confirm that oil and gas revenues affect royalties in both oil and neighboring municipalities. They also increase population, real wages, in particular in the manufacturing sector and in services, as well as local real prices and crime. Moreover, we observe negative spillovers of oil and gas revenues to wages and prices and positive spillovers on crime in neighboring municipalities.

The remainder of the paper is organized as follows. Section 2 presents our theoretical framework. Section 3 describes the data and presents our empirical strategy. Section 4 presents our main empirical results and robustness checks, followed by section 5 , which further investigates the nature of spillover effects. Finally, section 6 concludes. 


\section{The spatial distribution of the effect of oil and gas revenues: a framework}

\subsection{Effect on oil-producing municipalities}

The effect of an increase in oil and gas revenues may be gauged thanks to the theoretical frameworks provided by Moretti (2011) to investigate the arrival of a new producer in a municipality and Allcott and Keniston (2015) to discuss nature resources booms. On the positive side, an increase in oil and gas revenues allow oil sector workers to increase their demand of intermediate goods, that may be partly produced locally. Moreover, the revenues of oil-producing municipalities should increase, allowing them to increase their expenditures, resulting in an increased demand for goods and services. The direct effect of an increase in oil and gas revenues on local production is therefore likely positive. Moretti (2011) and Allcott and Keniston (2015) moreover stress that that positive effect may be magnified in the presence of agglomeration economies that would attract additional firms to oilproducing municipalities.

However, the framework of Moretti (2011) and Allcott and Keniston (2015) also implies that general equilibrium effects may mitigate direct and agglomeration effects. First, the increased demand for labor increases wages, hence the cost of labor. Whereas rising wages allow the booming oil-sector to attract workers and increase its production, rising labor costs reduce the production of other sectors. That effect may be particularly harmful to producers of goods that are traded with other municipalities, because thoseproducers are unable to increase their prices. As a result, the production of tradeable goods may move from oil-producing municipalities to other municipalities. Second, the prices of goods and services and of housing in oil-producing municipalities may increase due to the increase in labor costs, further increasing production costs for local producers and driving them away.

The relative magnitude of direct and general equilibrium effects is ambiguous. Accordingly, the effect of an increase in oil and gas revenues is a priori ambiguous. Whether it increases or decreases local production is therefore an empirical matter.

\subsection{Spatial spillovers of oil and gas revenues}

One may at first pass doubt that oil and gas revenues have any effect at all on other municipalities, if natural resources extraction comes in the guise of "enclaves" with high productivity but limited spillovers, as McMillan et al. (2014) document. Yet, whereas neighboring municipalities may not benefit from the direct effect of increased oil and gas revenues, they may be affected indirectly, because the indirect effects of oil and gas revenues may spread geographically.

On the positive side, neighboring municipalities may benefit from the increased demand for intermediate goods from oil-producing municipalities. How far those effects may spread depends on the nature of the spread of the supply chain of oil producers. Unless transportation costs are negligible, those supply-chain effects are likely smaller the more distant a municipality from the oil-producing municipality. Moreover, neighboring municipalities may benefit from the relocation of the production of tradeable goods driven away from oil-producing municipalities by rising wages. 
Another positive effect is specific to the way in which oil revenues are shared among Brazilian municipalities. Although the bulk of royalties accrues to oil-producing municipalities, neighboring municipalities are entitled to a small share of royalties if their land was used for oil post-product operations (i.e., storage and transportation). ${ }^{5}$ Accordingly, neighboring municipalities may also benefit from a small increase in public expenditures leading to an increase in the demandfor goods and services.

Conversely, neighboring municipalities may suffer from general equilibrium effects. In particular, the rise in the demand for labor in oil-producing municipalities is likely to spillover to neighboring municipalities, if workers are sufficiently mobile across municipalities, also resulting in an increase in prices. In addition, workers may migrate to oil-producing municipalities to meet the increased demand for labor in the oil sector.

Another source of negative spillovers would materialize if the increase in demand for goods and services in oil-producing municipalities also attracts scarce resources, like capital and skilled labor. That could worsen bottlenecks in non-oil municipalities and further decrease production. That could even reduce the demand for unskilled labor, resulting in lower wages.

Again, increased oil revenues can generate positive or negative spillovers on neighboring municipalities with the total effect being ambiguous. That ambiguity notwithstanding, it standsto reason that whatever spillovers there are will decrease with distance to oil production, as transport costs will dampen the effect of oil revenues on the relocation of tradeable goods and the migration of workers. We should therefore expect those effects to be strongest in the immediate vicinity of oil-municipalities.

\section{Empirical strategy and data}

\subsection{Empirical Strategy}

To gauge the direct and spill-over effects of oil and gas revenues on Brazilian municipalities, we estimate the following Spatial Durbin Model (SDM):

$$
\begin{aligned}
Y_{i s t}= & \rho W Y_{i s t}+\alpha_{1} \log \left(\text { Revenues }_{i s, 1992}\right)+\alpha_{2} W \log \left(\text { Revenues }_{i s, 1992}\right) \\
& +\beta X_{i s t}+\gamma W X_{i s t}+\delta_{i}+\eta_{t}+\varepsilon_{i s t}
\end{aligned}
$$

Where $Y_{i s t}$ is the relevant measure of economic activity of municipality $i$ in state $s$ and year $t ; \delta_{i}$ is municipality fixed effects; $\eta_{t}$ is year fixed effects; $X_{i s t}$ is a vector of time-varying controls and $\varepsilon_{j s t}$ is the error term. Municipality fixed effects control for the differences across municipalities that are constant over time, while year fixed effects control for changes in the variables that affect all municipalities in the same year.

The main explanatory variable is the logarithm of oil and gas revenues, $\log \left(\right.$ Revenues $\left._{i s, 1992}\right)$, computedas $O i l_{i s, 1992} \times P_{t}^{o i l}+G_{i s, 1992} \times P_{t}^{g a s}$, where $O i l_{i s, 1992}$ and $G_{i s, 1992}$ are the oil and gas

\footnotetext{
${ }^{5}$ See Monteiro and Ferraz (2010) for a detailed description of the distribution of oil royalties.
} 
production levels in municipality $i$ and state $s$ in 1992, and $P_{t}^{o i l}$ and $P_{t}^{g a s}$ are the international oil prices of oil and gas in yeart.

The spatial dimension of economic activity and spillovers of oil revenues are captured by the contiguity spatially weight matrix $W$, which defines potential interactions between each pair of municipalities. Two municipalities are considered as neighbors if they share a common border. A contiguous municipality is assigned a weight of 1 , while non-neighbors are assigned a weight of zero. Accordingly, $W Y_{i s t}$ is the average economic activity in the municipalities that are adjacent to municipality $i$ in state $s$ at time $t$ and parameter $\rho$ reflects the strength of spatial dependence in economic activities. By the same token, $W \log \left(\right.$ Revenues $\left._{i s, 1992}\right)$ denotes the logarithm of oil and gas revenues averaged over municipality i's neighbors.

The first parameter of interest is $\alpha_{1}$. It captures the direct effect on the activity of a municipality of the oil and gas revenues of that municipality. The second parameter of interest is $\alpha_{2}$, which measures the spillover on a municipality of oil and gas revenues in neighboring municipalities. Note that if $\rho=$ $\alpha_{2}=\gamma=0$, then the model reduces to a standard linear regression model.

The weight matrix $W$ implies that economic activity in a municipality is affected not only by the production and oil activity of its direct neighbors but also by all the other municipalities in the sample, because their neighbors have neighbors and so on. The magnitudes of $\alpha_{1}$, and $\alpha_{2}$ can therefore not be interpreted directly. We, therefore, compute and separately report the average effect of oil and gas revenues on economic activities within oil municipalities (direct effect), the average spillover effect to neighboring municipalities (indirect effect), and the average total effect (direct effect + indirect effect). The direct effect takes into account the feedback effects from neighboring municipalities in response to oil and gas revenues in municipality $i$. The total average effect measure can beinterpreted as the average total impact of oil and gas revenues on economic activities in a typical municipality if all municipalities had oil activities (Pace and LeSage, 2006). ${ }^{6}$

Beside the fact that the main aim of the paper is to distinguish the direct effect of oil and gas revenues on oil producing municipalities from the spillovers that may affect neighboring municipalities, ignoring the spatial terms in Equation 1 would bias the estimates of the causal effects of oil revenues on economic activity in the presence of spillovers. Specifically, the effect would be overestimated in the presence of negative spillovers and underestimated in the presence of positive spillovers.

To the extent that the prices of oil and gas are determined on the world market and Brazilian municipalities are therefore price takers, prices are exogenous to the local factors in Brazilian municipalities. Exogeneity is further ensured by fixing the level of oil production to its level at the beginning of the sample period. Doing so overcomes endogeneity problems that would appear if oil discovery efforts and extraction rates were correlated with economic activity. The variation of the value

\footnotetext{
${ }^{6}$ Another interpretation could be that the total average effect measures the total cumulative impact arising from oil activities in municipality $i$ on the economic activity of all other municipalities (on average) (Pace and LeSage, 2006).
} 
of oil production given by the product of the price of oil and initial production level is thereforeplausibly exogeneous and OLS estimates of $\alpha_{1}$ and $\alpha_{2}$ should be unbiased and reflect causal effects. ${ }^{7}$

\subsection{Data}

Our baseline dependent variable, economic activity, is measured using night-time light emissions. It comes from the National Oceanic and Atmospheric Administration's (NOAA) National Geophysical Data Center. We use the Defense Meteorological Satellite Program Operational Line scan System (DMSP-OLS) dataset providing a satellite-year dataset for the time period 1992 to 2013. It has been used as a proxy for GDP in recent studies (e.g. Doll et al., 2006; Henderson et al., 2012; Hodler and Raschky, 2014; Michalopoulos and Papaioannou, 2014; Keola et al., 2015). Night light emissions exhibit a strong correlation with GDP per capita (Henderson et al., 2012). The data is available at a very fine spatial resolution of approximately 1 square kilometer (30-arc seconds). It can therefore be aggregated at the level of Brazilian municipalities, which are our unit of observation. Figure 1 describes the borders of those municipalities.

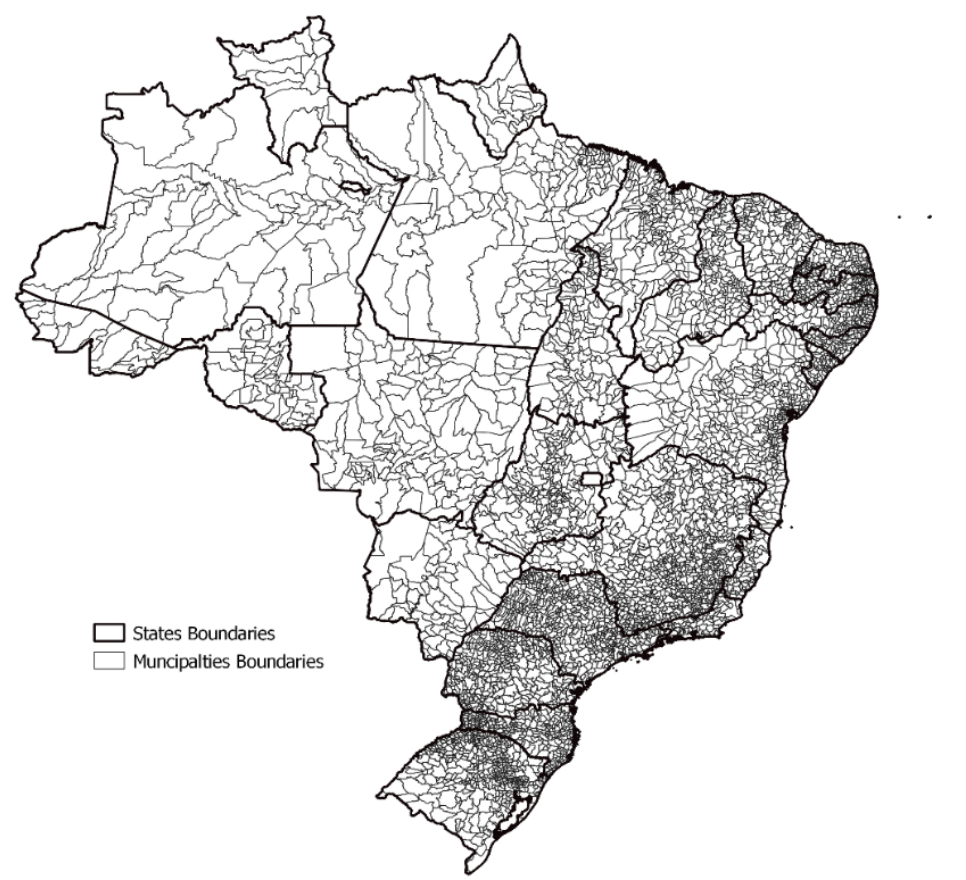

Notes: This map shows all Brazilian states and their corresponding municipalities (IBGE).

Fig. 1 Brazilian municipalities' boundaries

To construct the dataset, NOAA processes daily images taken by the U.S. Department of Defense weather satellites orbiting the earth 14 times per day. Each satellite observes every location on earth every night at some point in time between 20:30 and 22:00. NOAA removes observations biased by strong sources of natural light, e.g., the summer months when the sun sets late, light activity related

\footnotetext{
${ }^{7}$ Similar procedures were used by Dube and Vargas (2013) and Nunn and Qian (2014).
} 
to the northern and southern lights, and forest fires. Observations obscured by clouds are also excluded. The filtered daily images are then averaged for the entire year producing light intensity data ranging from 0 (no light) to 63, with higher values indicating greater luminosity. The result is a measure of night light intensity that only reflects human (economic) activity. ${ }^{8}$

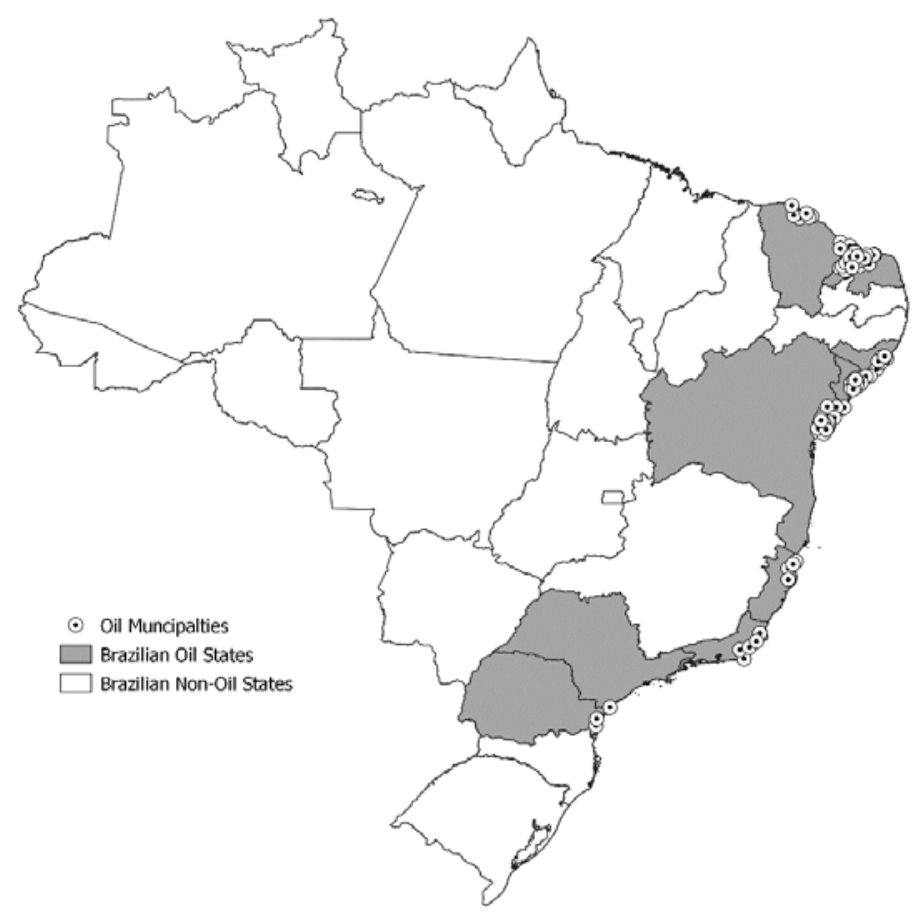

Notes: This map shows the locations of oil producing municipalities and their corresponding states. Oil municipalities are defined as municipalities that started oil production in 1992 . We exclude all municipalities that did not exist in 1991. Data from IBGE and ANP.

Fig. 2 Brazilian oil producing states and municipalities’ location

Night-lights data has a number of advantages over using official municipal GDP figures computed by the Brazilian national bureau of statistics (Instituto Brasileiro de Geografia e EstatísticaIBGE). First, the data has a longer time-series, as the official municipal GDP figures are only available on an annual basis from 1999 onward. Second, night-time lights data captures any type of economic activity, both official and non-official, especially at the sub-national level where official statistics are otherwise lacking or unavailable, in contrast to official GDP figures. Third, municipal GDP is not computed directly in Brazil. It is instead inferred from stateGDP divided among municipalities according to a numberof reference variables. For oil producing municipalities, the referencevariable used to assigni municipal industry GDP is the same as the one used to assign oil production to municipalities, creating a tautological correlation between oil production and of ficial GDP. Using night-time light emissions therefore allows us to study a relationship that is not a spurious artefact of the way Brazilian authorities impute state GDP to municipalities. Our data on oil production comes from Agencia Nacional de Petroleo

${ }^{8}$ See Henderson et al., 2012 for more technical information about the construction of the dataset. 
(ANP), which provides information on oil output, prices, and oil fields locations on a monthly basis. ${ }^{9} \mathrm{We}$ use this data to determine municipalities located over these oil fields and their production shares. We define oil municipalities as municipalities located over at least one oil field or part of it, with oil fields being in production phase in 1992.

International oil and gas prices were retrieved from International Financial Statistics. ${ }^{10}$ Figure 2 shows the locations of the oil-producing municipalities and the corresponding states. In the appendix, we explain in detail how we construct the annual oil production series for each municipality. ${ }^{11}$

Population, in logarithm, is controlled for in all regressions given its strong correlation with economic activity (Mamo et al., 2019). Data on annual municipality population is obtained from intercensus population estimates provided by IBGE. Because the SDM approach requires a strongly balanced dataset, missing municipal-year observations are filled in using linear interpolation to avoid the drop of municipalities with missing years. Table 1 reports the summary statistics for our variables of interest.

Table 1: Summary statistics

\begin{tabular}{lccccc}
\hline \hline Variable & $\mathbf{N}$ & Mean & SD & Min & Max \\
\hline Nighttime lights & 42680 & 4.99 & 9.25 & 0 & 63 \\
Revenues (log) & 42680 & 0.97 & 4.44 & 0 & 28.61 \\
Population (log) & 42680 & 9.71 & 1.13 & 6.58 & 16.29 \\
Distance to oil municipality & 42680 & 249.89 & 176.89 & 0.00 & 724.39 \\
\hline
\end{tabular}

Our period of analysis is 1992-2013. Our final baseline sample covers 1940 municipalities among which 91 produce oil. To consider a reasonably homogenous sample, we focus on the nine oilproducing states, namely Ceará (9 oil-producing municipalities), Rio Grande do Norte (16 municipalities), Alagoas (9 municipalities), Sergipe (19 municipalities), Bahia (26 municipalities), Espírito Santo (4 municipalities), Rio de Janeiro (5 municipalities), Sao Paulo (1 municipality), and Paraná (2 municipalities). ${ }^{12}$ The number and the size of Brazilian municipalities changed during the 1990s owing to the split and the merging of municipalities. We therefore restrict our sample to municipalities that existed in 1991 onward and exclude all municipalities that were founded afterwards. ${ }^{13}$ In all specifications, we cluster the standard errors at the municipal level.

\footnotetext{
${ }^{9}$ Each oil field produce oil and natural gas. Therefore, throughout the article we use "oil” to refer to both oil and natural gas.

${ }^{10}$ It should be noted that some oil municipalities are set to report zero oil production, because they started producing after 1992.

${ }^{11}$ We follow Caselli and Michaels (2013) in constructing the oil production figures for oil producing municipalities.

12 Ten other municipalities were also producing oil in 1992. However, eight out of these municipalities did not exist in 1991, but were carved out of existing municipalities and thus dropped. One municipality located in the state of Amazonas is excluded given its remote location from other oil-municipalities. The last municipality "Grossos” in state of Rio Grande do Norte is excluded given the unavailability of data on night light data.

${ }^{13}$ As robustness check, we also use the full sample of 2065 municipalities located in the oil producing states.
} 


\section{Baseline results}

\subsection{A first look at the data}

Figure 3 plots the average night-time light levels, net of municipality and year fixed effects, against international oil price separately for oil producing municipalities, in Panel A, and non-oil producing, in Panel B. Panel C reports the results pooling all Brazilian municipalities. ${ }^{14}$ The figure shows that the price of oil correlates positively with night-time light emissions in oil producing municipalities but negatively in non-oil producing municipalities. This finding suggests that while oilproducing municipalities benefit from an increase in the price of oil, other municipalities suffer from it.
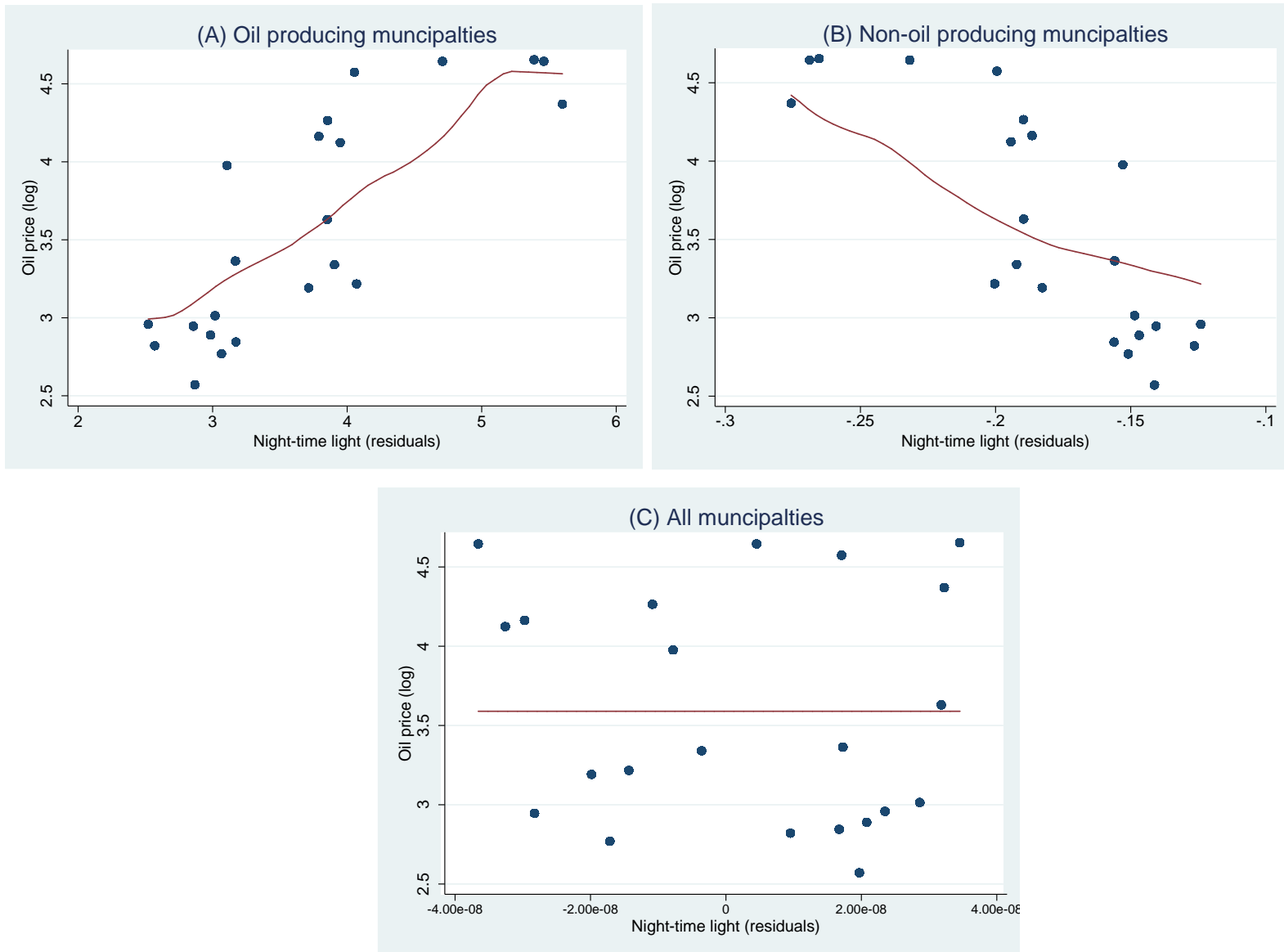

Notes: The graph shows the relationship between oil price and annually averaged night-time light in (A) oil producing municipalities; (B) non-oil producing municipalities; and (C) All Brazilian municipalities. The solid line represents the nonparametric local polynomial fit computed using an Epanechnikov kernel

Fig. 3 Effect of oil production on economic activity

In both plots, the nonparametric line suggests that the relationship is linear. Plotting all municipalities together, we see no relationship between the price of oil and night-time lights with the nonparametric line being flat. Accordingly, the previously depicted positive and negative relationships

\footnotetext{
${ }^{14}$ The estimation proceeds in two steps. In the first step, we regress night-time light on municipality fixed effects and year fixed effects. Then we take the residuals and use the nonparametric local polynomial estimator to examine the relationship between oil price and annually averaged night-time light.
} 
cancel out each other when combined together. ${ }^{15}$

\subsection{Findings}

Table 2 reports the results from estimating Equation (1) using various sample compositions and variable definitions. The baseline sample is restricted to municipalities located in the nine oil-producing states. In Column 1, oil production is fixed at 1992 levels, the production of municipalities that started producing after 1992 being set to zero. Column 1 reports a restricted version of Equation 1 where $\alpha_{1}$ and $\alpha_{2}$ are set to zero. In other words, the column reports the OLS estimates of Equation (1). It shows that the coefficient of oil and gas revenues is positive and statistically significant at the one-percent level. Thus, a rise in oil and gas revenues increases economic activity, as measured by light emissions, in oil producing municipalities. That finding is in line with previous studies reporting a positive effect of natural resources on economic activity in areas where production is located (Black et al., 2005, Allcot and Keniston, 2018, Michaels, 2011, Aragón and Rud, 2013, Gradstein and Klemp, 2016, and Mamo et al., 2019).

Columns 2 to 4 explicitly tackle spatial spillovers by reporting the spatial Durbin model estimates of Equation (1), including the spatial lags of oil revenues and night-time light variables. In all those models, the spatial autoregressive parameter $\rho$ is positive and statistically significant beyond the one-percent level, reflecting a strong correlation in economic activity across municipalities. Accordingly, a contemporaneous increase in economic activity in a neighboring municipality induces a 0.17 point increase in economic activity in the municipality itself.

Column 2 reports the estimation of Equation (1) on the baseline sample. The coefficient of oil and gas revenues remains positive and statistically significant at the one-percent level of significance. The key new insight is provided by the coefficient of the spatial lag of oil and gas revenues, which is statistically significant at the five-percent level suggesting that the effect of oil and gas revenues spills over to neighboring municipalities. In addition, its magnitude is similar to the magnitude of the coefficient of oil and gas revenues in the municipality, indicating that economic activity in neighboring municipalities is expanding by less than the average that one would expect from the positive spatial correlation pattern observed in night-time lights as previously indicated by autoregressive parameter $\rho$.

Panel B reports the estimates of the implied direct effect of oil and gas revenues within an oil municipality, of the indirect average spillover effect in the neighboring municipalities, and of the total average effect, which is the sum of direct and indirect effects. It thereby gives the quantitative significance of our effects. The direct effect of oil and gas revenues within oil municipalities is positive and statistically significant. The coefficient of the direct effect of oil and gas revenues is about $13 \%$ lower than in Column 1 and implies that a 10 percent increase in oil and gas revenues boosts economic activity by 0.07 luminositypoints. With an average night-time light emission of 4.99 in our sample, that

\footnotetext{
${ }^{15}$ We get the same results when we use international gas prices (results not reported for brevity).
} 
coefficient translates to an average 1.4 percent increase in economic activity in oil-producing municipalities.

The indirect spillover effect in neighboring municipalities is negative and significant, suggesting that oil and gas revenues reduce economic activity in neighboring municipalities. Furthermore, the spillover effect is nearly of the same magnitude as the direct effect. As a result, the total average effect is small and statistically insignificant, since the positive direct effect and negative indirect effect cancel each other out.

Table 2: Effect of oil and gas revenues on economic activity

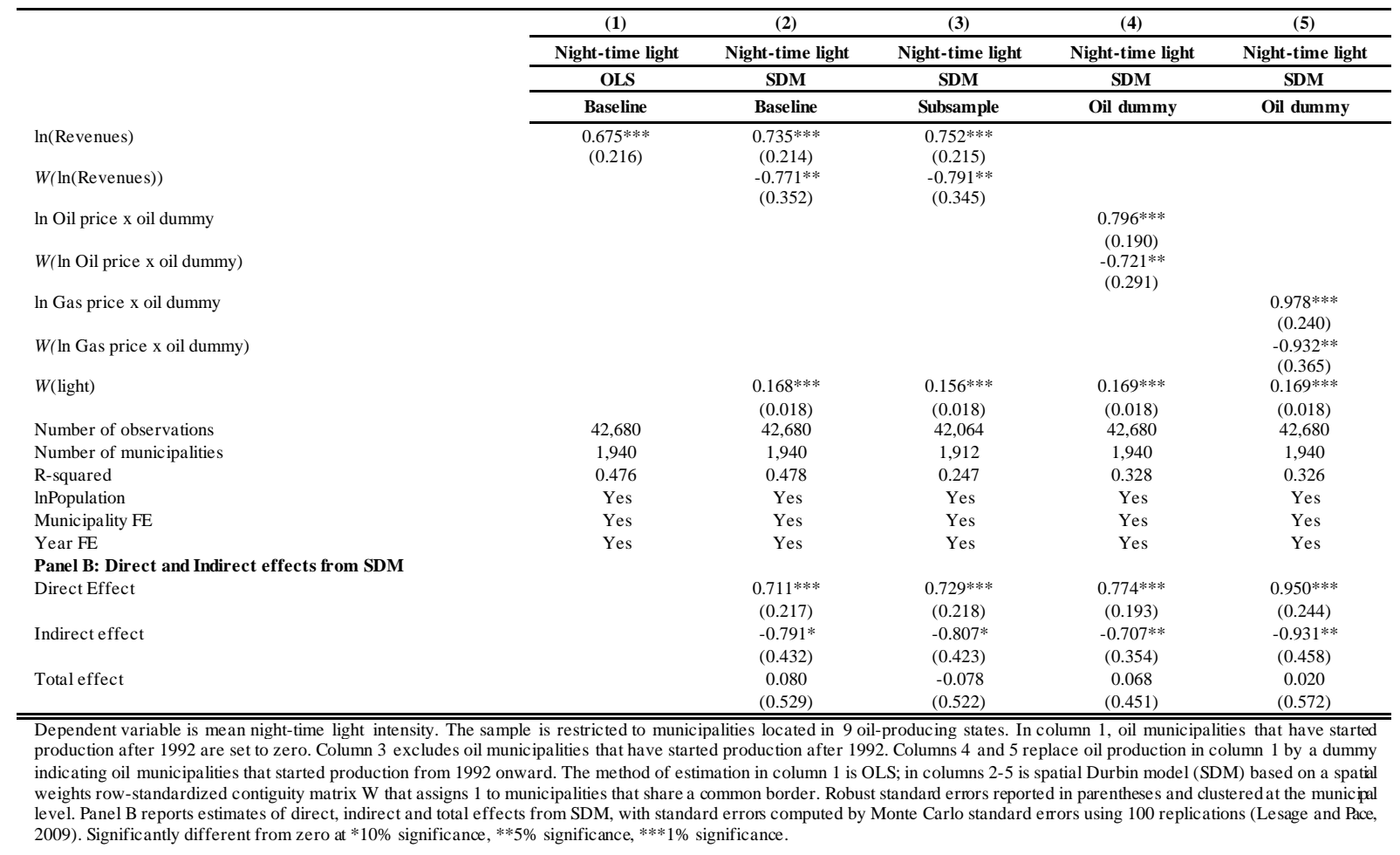

Considering that all municipalities that had not started producing oil in 1992 received no revenues throughout the period even though a municipality may have started its production in the following year may result in an attenuation bias. As an alternative, in Column 3, we estimate Equation (1) on a subsample of municipalities excluding municipalities that started producing oil after 1992. The coefficients of oil and gas revenues and of their spatial lag both slightly increase in magnitude but keep their signs and significance levels. The magnitudes of the direct, indirect, and total average effects also increase, and their signs and levels of statistical significance also remain unchanged, showing that our baseline finding was not driven by our hypothesis on the onset of oil production.

To address concerns of an attenuation bias due to measurement error, we replace oil production in Column 4 by a dummy variable that takes a value of 1 , if the municipality is producing oil from 1992 onward and multiply it by the international price of oil. The coefficients of oil and gas revenues and of their spatial lag remain stable in sign and significance, as well as their associated direct, indirect and 
total effects. Similarly, in Column 5, we multiply the dummy indicating oil municipalities by the log of international gas price and our results remain.

Overall, our results suggest large negative spillover effects from oil and gas revenues. A tenpercent increase in oil and gas revenues reduces economic activity in neighboring municipalities by around 0.08 units of luminosity on average. Ignoring those spillovers would give a biased picture of the total effect of oil and gas revenues. While oil producing municipalities seem to benefit from an increase in oil and gas revenues, neighboring oil municipalities suffer from it. As a result, the aggregate effect of oil and gas revenues on economic activity is negligible, which may explain the contradictory findings of the literature (Sachs and Warner, 1995, 2001, Auty, 2001, Alexeev and Conrad, 2009).

\subsection{Robustness checks}

In our baseline specification, we examine the effect of the sum of oil and gas revenues on night-time lights. Yet, oil and gas revenues may affect the economy differently. In Columns 1 and 2 of Table 3, we therefore differentiate the effect of revenues generated by the production of the two hydrocarbons. In both models, we still see a positive direct impact of oil and gas revenues on night-time light emissions within producing municipalities, whereas the neighboring municipalities bear negative spillovers and the total effect remains small and statistically insignificant.

Looking at the distribution of night-time light emissions, we find that around 99 percent of observations lie between 0 and 54, with about 1 percent of observations taking the extreme values of 0 and beyond 54 . To make sure that our findings are not driven by those extreme observations, we winsorize extreme values by replacing them with the next highest (lowest) observation. This ensures that all observations are used and the effect of possibly spurious outliers is reduced. The second column of Table 3 contains the results of a regression estimating Equation (1) with winsorized night-time lights. The main results do not differ: the direct effect of oil and gas revenues on economic activity is positive and significant within oil municipality; the spillover effect to neighboring municipalities is negative and quantitatively larger than the direct effect; and the overall effect is small and insignificant.

One may argue that the effect of oil and gas revenues only materializes with a lag and that using its contemporaneous value underestimates it. In Column 3 of Table 3, we therefore lagged oil revenues by one year. Again, the estimated coefficients and the associated effects change neither in sign, magnitude, or statistical significance. This ensures that the baseline results were not driven by the lag structure. ${ }^{16}$

Equation (1) is static and therefore does not take the inertia of economic activity into account. We therefore estimated a fully dynamic autoregressive SDM by adding the lagged dependent variable to the explanatory variables. The coefficient of lagged night-time lights is positive and statistically significant. However, although the coefficient of oil revenues drops in size, it remains statistically significant. The coefficient on spatial lagged oil revenues remains negative, but loses its statistical

${ }^{16}$ We also checked with using the 2-year lag and results remain robust (results reported in Appendix B ). 
significance. However, the estimated direct, indirect and total effects remain unchanged. The long-run direct effect is larger than the short-run effect, suggesting that night-time light adjusts very slowly, so that the direct effect of oil revenues on economic activity in oil municipalities is around $400 \%$ larger in the long run.

Table 3: Effect of oil and gas revenues on economic activity - Robustness checks

\begin{tabular}{|c|c|c|c|c|c|}
\hline & (1) & (2) & (3) & (4) & (5) \\
\hline & Light & Light & Light & Light & Light \\
\hline & SDM & SDM & SDM & SDM & SDM \\
\hline & $\begin{array}{c}\text { Oil production } \\
\text { only }\end{array}$ & $\begin{array}{c}\text { Gas production } \\
\text { only }\end{array}$ & $\begin{array}{l}\text { Winzorising extreme } \\
\text { values }\end{array}$ & $\begin{array}{c}\text { Lagged oil and gas } \\
\text { revenues }\end{array}$ & Add dynamics \\
\hline \multicolumn{6}{|c|}{ Panel A: Estimated Coefficients } \\
\hline $\ln$ (Oil revenues) & $\begin{array}{c}0.702 * * * \\
(0.186)\end{array}$ & & & & \\
\hline$W(\ln ($ Oil revenues $))$ & $\begin{array}{l}-0.582^{*} \\
(0.307)\end{array}$ & & & & \\
\hline $\ln$ (Gas revenues) & & $\begin{array}{c}0.804 * * * \\
(0.231)\end{array}$ & & & \\
\hline$W(\ln ($ Gas revenues $))$ & & $\begin{array}{c}-0.768^{* *} \\
(0.374)\end{array}$ & & & \\
\hline $\ln$ (Revenues) & & & $\begin{array}{c}0.737 * * * \\
(0.213)\end{array}$ & & $\begin{array}{c}0.204 * * * \\
(0.078)\end{array}$ \\
\hline$W(\ln ($ Revenues $))$ & & & $\begin{array}{c}-0.790 * * \\
(0.349)\end{array}$ & & $\begin{array}{l}-0.112 \\
(0.114)\end{array}$ \\
\hline $\ln$ (Revenues), $\mathrm{t}-1$ & & & & $\begin{array}{c}0.764 * * * \\
(0.214)\end{array}$ & \\
\hline$W(\ln ($ Revenues) $), \mathrm{t}-1$ & & & & $\begin{array}{c}-0.721^{* *} \\
(0.353)\end{array}$ & \\
\hline$W$ (light) & $\begin{array}{c}0.169 * * * \\
(0.018)\end{array}$ & $\begin{array}{c}0.168 * * * \\
(0.018)\end{array}$ & $\begin{array}{c}0.162^{* * *} \\
(0.018)\end{array}$ & $\begin{array}{c}0.170^{* * *} \\
(0.018)\end{array}$ & $\begin{array}{c}0.125^{* * *} \\
(0.011)\end{array}$ \\
\hline Light, t-1 & & & & & $\begin{array}{c}0.793 * * * \\
(0.013)\end{array}$ \\
\hline Number of observations & 42,680 & 42,680 & 42,680 & 40,740 & 40,740 \\
\hline Number of municipalities & 1,940 & 1,940 & 1,940 & 1,940 & 1,940 \\
\hline R-squared & 0.287 & 0.255 & 0.265 & 0.257 & 0.963 \\
\hline InPopulation & Yes & Yes & Yes & Yes & Yes \\
\hline Municipality FE & Yes & Yes & Yes & Yes & Yes \\
\hline Year FE & Yes & Yes & Yes & Yes & Yes \\
\hline \multicolumn{6}{|c|}{ Panel B: Direct and Indirect effects from SDM } \\
\hline Direct Effect & $\begin{array}{c}0.685 * * * \\
(0.189)\end{array}$ & $\begin{array}{c}0.781^{* * *} \\
(0.235)\end{array}$ & $\begin{array}{c}0.713^{* * *} \\
(0.216)\end{array}$ & $\begin{array}{c}0.743 * * * \\
(0.216)\end{array}$ & $\begin{array}{c}0.194 * * * \\
(0.066)\end{array}$ \\
\hline Direct Effect (Long run) & & & & & $\begin{array}{c}0.945 * * * \\
(0.365)\end{array}$ \\
\hline Indirect effect & $\begin{array}{l}-0.567 \\
(0.370)\end{array}$ & $\begin{array}{l}-0.778^{*} \\
(0.463)\end{array}$ & $\begin{array}{r}-0.812^{*} \\
(0.425)\end{array}$ & $\begin{array}{l}-0.711^{*} \\
(0.411)\end{array}$ & $\begin{array}{l}-0.110 \\
(0.134)\end{array}$ \\
\hline Indirect effect (Long run) & & & & & $\begin{array}{l}-0.037 \\
(1.501)\end{array}$ \\
\hline Total effect & $\begin{array}{c}0.118 \\
(0.462)\end{array}$ & $\begin{array}{c}0.003 \\
(0.566)\end{array}$ & $\begin{array}{l}-0.098 \\
(0.517)\end{array}$ & $\begin{array}{c}0.032 \\
(0.489)\end{array}$ & $\begin{array}{c}0.084 \\
(0.148)\end{array}$ \\
\hline Total effect (Long run) & & & & & $\begin{array}{c}0.908 \\
(1.717)\end{array}$ \\
\hline
\end{tabular}

Table 4 reports a series of robustness checkspertaining to the sample of municipalities. We have so far restricted our sample to the municipalities that existed throughout our period of study, thereby overlooking municipalities that appeared during the period. To make sure that this did not drive our baseline results, we included all municipalities in the 9-oil producing states taking into account the ones that did not exist in 1991. Column 1 of Table 4 shows that the estimated coefficient on oil and gas revenues becomes slightly larger, but the coefficient of its spatial lag increases by around 17 percent. The same is true for their associated estimated effects. All coefficients remain unchanged in their signs and statistically significance. 
Table 4: Effect of oil revenues on economic activity - Robustness checks

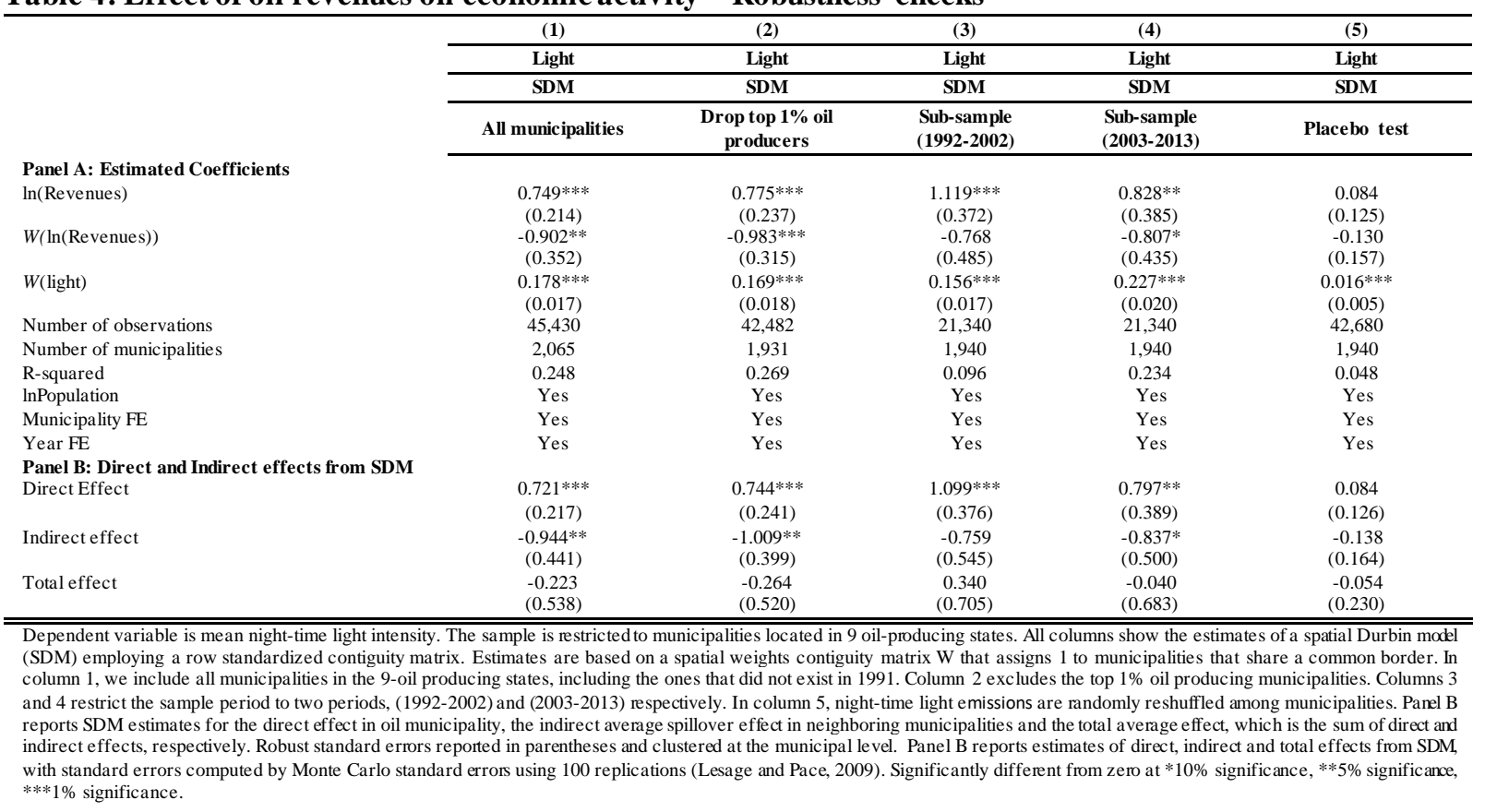

Another way to make sure that our results are not driven by outliers is to simply drop extreme observations. We accordingly dropped the top $10 \%$ oil producing municipalities in terms of oil production and estimated Equation (1) anew. ${ }^{17}$ The outcome of that estimation is reported in Column 2 of Table 4. Again, dropping large producers of oil does not affect the baseline results, in terms of either statistical or quantitative significance. ${ }^{18}$

To see if the baseline results are driven by a specific period of time, we split the sample into two sub-periods of equal length, specifically pre-2003 and post-2003 and run a regression for each period separately. The two regressions are reported in Columns 3 and 4 of Table 4 . The coefficient of oil and gas revenues is positive and statistically significant in both regressions. The spatial lag of oil and gas revenues is statistically significant only for the post-2003 period. This finding may be driven by the smaller size of the sample or suggest that spillovers essentially materialized in the second period. The estimated direct, indirect, and total effects for both samples follow the same patterns. In addition, the positive direct effect of oil revenues is always compensated by the negative spillover effect, so that the total effect is statistically insignificant, like in our baseline results.

In Column 5, we address the concern that time-varying omitted variables could be driving the estimated relationship between economic activity and oil revenues. Indeed, it could be the case that the residual unobserved heterogeneity still co-moves with the world oil prices despite the wide array of fixed effects we include. To rule that possibility out, we perform a placebo test by randomly reshuffling night-time light observations among municipalities before estimating Equation (1) again. Although the coefficient of the spatially lagged dependent variable remains positive and statistically significant, the

\footnotetext{
${ }^{17}$ The dropped oil municipalities are Açu, Areia Branca, Alagoinhas, Catu, Cabo Frio, Campos dos Goytacazes, Casimiro de Abreu, Macaé, and Quissamã.

${ }^{18}$ Further robustness checks reported in Appendix B include dropping capital municipalities and lights $>99^{\text {th }}$ percentile. Our main results remain robust.
} 
coefficients of oil revenues and of their spatial lag as well as the estimated direct and indirect effect all become statistically insignificant and very small in magnitude. As the placebotest results in insignificant results, we can safely conclude that our baseline results are not driven by co-movements in oil prices and economic activity.

\section{Extensions}

\subsection{How spillovers fade with distance}

We have so far taken the spatial dimension of spillovers into account by defining proximity as adjacency, in line with the SDM. To go beyond that definition and see how far oil production in one municipality affects other municipalities, we complement our baseline results by using crow-fly distance to the nearest oil-producing municipality. To allow the relationship to be non-linear, we define exposure to oil production in ring $k$ as:

$$
\text { Exposure }_{i s k}=\log \left(\text { Revenues }_{j s}\right) \times \text { ring }_{i j k}
$$

where $r i n g_{i j k}$ is a dummy variable set to one if a municipality $i$ in state $s$ lies within a certain range $k$ from oil municipality $j$.

To define the rings' width, we choose a baseline distance cut-offs of 50, 100, 150, 200, 250, 300 , and more than $300 \mathrm{~km} .{ }^{19}$ Choosing a $50 \mathrm{~km}$ distance as a starting point is fairly reasonable for two reasons: First, the number of municipalities below $50 \mathrm{~km}$ distance is small, hence introducing more noise and reducing the power of the results; Second, given that oil municipalities are moderately spatially clustered, by employing distance below $50 \mathrm{~km}$, we could be end up capturing the effect of the oil municipality itself rather than the surrounding non-oil areas. The latter concern is known as overglow phenomenon of night-time lights driven by lights emanating from the oil industry itself (i.e. gas flares or construction sites). Such overglow effects become smaller after $50 \mathrm{~km}$ (Pinkovskiy, 2016). ${ }^{20}$

The spillover effect is then estimated by running the following regression:

$$
\begin{aligned}
Y_{i s t} & =\alpha_{i}+\vartheta_{t}+\beta_{2} \log \left(\text { Revenues }_{i s, 1992}\right)+\sum_{k} \beta_{k} \text { Exposure }_{i s k} \\
& +\varphi X_{i s t}+\mu_{i s t}
\end{aligned}
$$

where $\alpha_{i}$ and $\vartheta_{t}$ are municipality and year fixed effects. $\beta_{2}$ measures the direct effect of oil and gas revenues on economic activity in oil municipalities (i.e. ring $=0 \mathrm{~km}$ ) and $\beta_{k}$ captures the spillover effect of oil production on economic activity in municipalities located within a certain ring from oil municipalities. Total spillover effects are, therefore, estimated by examining the effect of oil revenues

\footnotetext{
${ }^{19}$ Distance thresholds are calculated based on the centroids of municipa lities.

${ }^{20}$ As a robustness check, we also tried cut-offs of 100, 200, 300, and more than $300 \mathrm{~km}$ and results remain unchanged. The results are reported in the appendix.
} 
aggregately within all rings at once, with each ring excluding from its range the preceding one. For instance, if we are at the $100 \mathrm{~km}$ radius, we exclude from it the $50 \mathrm{~km}$ radius and so on.

Table 5 presents the results from estimating Equation(2). The direct effect of oil revenues on economic activity in oil municipalities remains positive and statistically significant. As we move away from oil municipalities, the effect becomes statistically insignificant in the 50 and $100 \mathrm{~km}$ rings. We observe a negative effect of oil statistically significant at the five-percent level in the ring ranging from 100 to $150 \mathrm{~km}$. The effect is statistically insignificant at standard levels in the next three rings, specifically $150-200 \mathrm{~km}, 200-250 \mathrm{~km}$, and 250-300 km. Beyond $300 \mathrm{~km}$, the spillover effect of oil revenues is negative and weakly statistically significant at the ten-percent level.

Table 5: Effect of oil revenues on economic activity - Extensions

\begin{tabular}{|c|c|c|c|c|c|c|}
\hline & $(1)$ & (2) & (3) & (4) & (5) & (6) \\
\hline & Light & Light & Light & Light & Light & Light \\
\hline & OLS & OLS & OLS & OLS & OLS & OLS \\
\hline & Ring & $\begin{array}{l}\text { Distance to oil } \\
\text { municipality }\end{array}$ & $\begin{array}{l}\text { Distance to oil } \\
\text { municipality }\end{array}$ & Micro-region & Micro-region & Macro-region \\
\hline In(Revenues) & $\begin{array}{l}0.443^{* *} \\
(0.225)\end{array}$ & & & $\begin{array}{c}0.075 \\
(1.306)\end{array}$ & $\begin{array}{c}-3.279^{\star * *} \\
(1.058)\end{array}$ & $\begin{array}{l}-5.555 \\
(7.800)\end{array}$ \\
\hline Exposure $<=50$ & $\begin{array}{l}-0.066 \\
(0.296)\end{array}$ & & & & & \\
\hline Exposure $<=100$ & $\begin{array}{l}-0.260 \\
(0.351)\end{array}$ & & & & & \\
\hline Exposure $<=150$ & $\begin{array}{c}-0.600^{* *} \\
(0.291)\end{array}$ & & & & & \\
\hline Exposure $<=200$ & $\begin{array}{l}-0.328 \\
(0.310)\end{array}$ & & & & & \\
\hline Exposure $<=250$ & $\begin{array}{c}0.278 \\
(0.332)\end{array}$ & & & & & \\
\hline Exposure $<=300$ & $\begin{array}{l}-0.075 \\
(0.200)\end{array}$ & & & & & \\
\hline Exposure $>300$ & $\begin{array}{l}-0.254^{*} \\
(0.137)\end{array}$ & & & & & \\
\hline In Oil Price & & $\begin{array}{l}2.048^{\star \star \star} \\
(0.062)\end{array}$ & & & & \\
\hline In Oil Price $x$ Distance to oil municipality & & $\begin{array}{c}-0.001^{\star * *} \\
(0.000)\end{array}$ & & & & \\
\hline $\begin{array}{l}\text { In Gas Price } \\
\text { In Gas Price x Distance to oil municipality }\end{array}$ & & & $\begin{array}{l}2.457^{\star * *} \\
(0.076) \\
-0.001^{\star \star \star} \\
(0.000)\end{array}$ & & & \\
\hline Number of observations & 42,680 & 42,680 & 42,680 & 5,346 & 5,346 & 1,298 \\
\hline Number of municipalities/Micro regions & 1,940 & 1,940 & 1,940 & 243 & 243 & 59 \\
\hline R-squared & 0.481 & 0.478 & 0.477 & 0.592 & 0.574 & 0.673 \\
\hline InPopulation & Yes & Yes & Yes & Yes & Yes & Yes \\
\hline Municipality FE & Yes & Yes & Yes & Yes & Yes & Yes \\
\hline Year FE & Yes & Yes & Yes & Yes & Yes & Yes \\
\hline
\end{tabular}

In the second column of Table 5, we follow Gradstein and Klemp's (2016) specification and replace the distance dummies by a continuous measure of crow-fly distance, which we interact with the international price of oil. The direct effect of the price of oil on economic activity is positive and statistically significant at the one-percent level. The estimated coefficient implies that a 10 percent increase in oil price raises economic activity by 0.20 percentage point in oil-producing municipalities, that is when distance is zero. The interaction effect is negative and significant at the one-percent level, suggesting that the positive effect of oil fades as onemoves away from oil municipalities. Quantitatively, the average distance to an oil producing municipality is $291 \mathrm{~km}$, so that the coefficient of the conditional effect implies that a 10 percent increase in oil price increase economic activity in a non-oil municipality with an average distance from an oil municipality by 0.18 points. This is 10 percent lower than the 
increase in economic activity in oil municipalities. This result replicates the finding of Gradstein and Klemp (2016) the effect fades with distance but remains positive. In contrast to our previous findings, the effect of oil never turns out negative. The linear specification that Gradstein and Klemp (2016) use, and that we use here, therefore hides the negative spillovers that we observe with the SDM and the nonlinear model. The result is not confined to using oil price, in fact we obtain the same results in Column 3 , when interacting the distance to oil municipality with the international price of gas. The coefficients of (log) gas price and interaction term are almost of the same magnitude as in Column 2.

To further explore the general equilibrium effects of oil production, we follow Mamo et al. (2019) and redefine the unit of observation to correspond to the next higher administrative level. The idea here is that by doing so we define geographic units that internalize a part of the spillover effects. The larger the administrative unit, the larger the share of spillover effects that is internalized. We therefore conduct our analysis at the micro-region level, which is a grouping of economically integrated contiguous municipalities with similar geographic and productive characteristics, then at the level of macro-regions, the next highest administrative level. Micro-regions closely parallel the notion of local economies and have been widely used as the units of analysis in the literature on effects of trade liberalization on local labor markets in Brazil (Dix-Carneiro and Kovak, 2015; Dix-Carneiro, Soares and Ulyssea, 2018). The average micro-region in our sample comprises eight municipalities with a maximum number of 41 municipalities and an average size of 5,000 square kilometers. Macro-regions feature, on average, 33 municipalities and have an average size of 22,000 square kilometers.

When estimating Equation (1) on micro- and macro- region, we expect the coefficient of oil revenues to be smaller than in the baseline regressions or even statistically insignificant, owing to the fact the positive direct effects from oil and gas revenues and the negative spillovers may cancel out. Column 3 of Table 5 reports the outcome of that estimation. In line with our previous results signaling the presence of negative spillovers, the coefficient of oil and gas revenues is statistically insignificant. In the aggregate, the direct positive effect and negative spillover effects therefore cancel out. Column 4 reports the results obtained using macro-regions, the next highest administrative level, as our unit of observation. The coefficient of interest remains statistically insignificant. In addition, it is now negative, suggesting that it internalizes a larger share of negative spillovers. Overall, the results of those extra regressions confirm that oil and gas revenues generate large and negative spatial spillovers on neighboring municipalities, rendering the total impact of oil revenues on economic activities in all municipalities insignificant.

Finally, we follow another specification used by Mamo et al. (2019) and try to measure spillover effects only by simply excluding from the aggregation by microregion night-time light pixels adhering to oil municipalities before re-estimating Equation (1). As we exclude the activity from the municipalities that directly benefit from oil production and our results point to negative spillovers, we expect the effect to be negative and statistically significant. The outcome of that regression is reported 
in Column 5. The effect of oil revenues is indeed now negative and statistically significant. Those results therefore confirm the presence of negative spillovers from oil and gas revenues.

\subsection{Transmission channels of oil revenues to the economic activity}

We now turn to the drivers behind the effect of oil revenues. To do so, we consider a series of alternative dependent variables that may all be affected by oil production.

Table 6 - Drivers of economic activity

\begin{tabular}{|c|c|c|c|c|c|c|c|c|}
\hline & (1) & (2) & (3) & (4) & (5) & (6) & (7) & (8) \\
\hline & Log(Royalties) & Log(Population) & $\begin{array}{c}\text { Real Wages } \\
\text { - All Sectors }\end{array}$ & $\begin{array}{l}\text { Real Wages - } \\
\text { Manufacturing }\end{array}$ & $\begin{array}{c}\text { Real Wages - } \\
\text { Agriculture }\end{array}$ & $\begin{array}{c}\text { Real Wages - } \\
\text { Service }\end{array}$ & $\begin{array}{l}\text { Local real } \\
\text { prices }\end{array}$ & Log(Crime) \\
\hline & SDM & SDM & SDM & SDM & SDM & SDM & SDM & SDM \\
\hline \multicolumn{9}{|c|}{ Panel A: Estimated Coefficients } \\
\hline In(Revenues) & $\begin{array}{l}0.694^{* * *} \\
(0.149)\end{array}$ & $\begin{array}{c}0.095 * * * \\
(0.012)\end{array}$ & $\begin{array}{c}65.952 * * * \\
(19.32)\end{array}$ & $\begin{array}{l}92.514^{*} \\
(54.469)\end{array}$ & $\begin{array}{l}-13.064 \\
(14.261)\end{array}$ & $\begin{array}{l}\text { 257.331* } \\
(134.875)\end{array}$ & $\begin{array}{c}20.297 * * * \\
(2.543)\end{array}$ & $\begin{array}{c}0.308^{* * * *} \\
(0.041)\end{array}$ \\
\hline$W(\operatorname{In}($ Revenues) & $\begin{array}{c}0.075 \\
(0.052)\end{array}$ & $\begin{array}{l}-0.007 \\
(0.027)\end{array}$ & $\begin{array}{r}-26.188 \\
(22.876)\end{array}$ & $\begin{array}{c}-84.773 * * \\
(42.542)\end{array}$ & $\begin{array}{c}-113.353^{* * * *} \\
(17.402)\end{array}$ & $\begin{array}{c}-927.823^{* * * *} \\
(233.099)\end{array}$ & $\begin{array}{c}-20.147^{* *} \\
(9.722)\end{array}$ & $\begin{array}{c}0.352 * * * \\
(0.081)\end{array}$ \\
\hline$W$ (Dependent Variable) & $\begin{array}{c}0.012 \\
(0.008)\end{array}$ & $\begin{array}{c}0.152^{* * *} \\
(0.017)\end{array}$ & $\begin{array}{c}0.111^{* * *} \\
(0.015)\end{array}$ & $\begin{array}{c}0.063^{* * *} \\
(0.020)\end{array}$ & $\begin{array}{c}0.141^{* * *} \\
(0.018)\end{array}$ & $\begin{array}{c}0.218^{* * *} \\
(0.014)\end{array}$ & $\begin{array}{l}0.046^{*} \\
(0.025)\end{array}$ & $\begin{array}{c}0.168^{* * *} \\
(0.007)\end{array}$ \\
\hline Number of observations & 29,100 & 42,680 & 23,286 & 18,888 & 20,472 & 23,280 & 31,977 & 42,680 \\
\hline Number of municipalities & 1,940 & 1,940 & 1,940 & 1,574 & 1,706 & 1,940 & 1,683 & 1,940 \\
\hline R-squared & 0.952 & 0.478 & 0.866 & 0.096 & 0.148 & 0.359 & 0.119 & 0.054 \\
\hline Ln(Population) & Yes & No & Yes & Yes & Yes & Yes & Yes & Yes \\
\hline Municipality FE & Yes & Yes & Yes & Yes & Yes & Yes & Yes & Yes \\
\hline $\begin{array}{l}\text { Year FE } \\
\text { Panel B: Direct and Indi } \\
\text { from SDM }\end{array}$ & Yes & Yes & Yes & Yes & Yes & Yes & Yes & Yes \\
\hline Direct Effect & $\begin{array}{l}0.695^{\star \star *} \\
(0.150)\end{array}$ & $\begin{array}{c}0.095 * * * \\
(0.012)\end{array}$ & $\begin{array}{c}65.753^{* * * *} \\
(19.314)\end{array}$ & $\begin{array}{l}91.711^{*} \\
(54.610)\end{array}$ & $\begin{array}{l}-16.865 \\
(14.125)\end{array}$ & $\begin{array}{l}\text { 218.044* } \\
\text { (134.620) }\end{array}$ & $\begin{array}{c}20.089 * * * \\
(2.509)\end{array}$ & $\begin{array}{c}0.322 * * * \\
(0.042)\end{array}$ \\
\hline Indirect effect & $\begin{array}{l}0.081^{*} \\
(0.052)\end{array}$ & $\begin{array}{c}0.011 \\
(0.032)\end{array}$ & $\begin{array}{l}-15.432 \\
(24.998)\end{array}$ & $\begin{array}{l}-73.906 * \\
(41.438)\end{array}$ & $\begin{array}{c}-125.665 * * * \\
(18.888)\end{array}$ & $\begin{array}{c}-1,022.539 * * * \\
(270.262)\end{array}$ & $\begin{array}{c}-20.950^{* *} \\
(8.568)\end{array}$ & $\begin{array}{c}0.454^{* * * *} \\
(0.099)\end{array}$ \\
\hline Total effect & $\begin{array}{c}0.777^{\star \star \star} \\
(0.137)\end{array}$ & $\begin{array}{c}0.106 * * * \\
(0.035)\end{array}$ & $\begin{array}{l}50.303^{*} \\
(30.364)\end{array}$ & $\begin{array}{c}17.805 \\
(68.856)\end{array}$ & $\begin{array}{c}-142.529 * * * \\
(22.680)\end{array}$ & $\begin{array}{l}-804.495^{* * *} \\
(306.618)\end{array}$ & $\begin{array}{r}-0.860 \\
(8.506)\end{array}$ & $\begin{array}{c}0.776^{* * * *} \\
(0.117)\end{array}$ \\
\hline
\end{tabular}

Municipalities that neighbor an oil-producing municipality are also entitled to a small share of royalties, if their land was used for oil post-product operations (i.e., storage and transportation). Data on oil royalties (measured in real terms and expressed in US dollars) are obtained from Agencia Nacional de Petroleo (ANP) for the period 1999-2013. In Column 1 of Table 6, we look at the effect of oil revenues on total royalties received. The estimated coefficient of the direct effect is positive and statistically significant at the one-percent level. The coefficient of its spatial lag is positive, but much smaller in magnitude and significance. Quantitatively, a 10 percent increase in oil and gas revenues results in a 7 percent increase in royalties received by oil municipalities compared to 1 percent increase in neighboring municipalities. The total effect is positive and statistically significant, and mostly driven by the direct effect, confirming that royalties are to a large extent a local phenomenon and exert limited spillovers. The coefficient of the spatial lag of royalties is positive and significant but is very small in size suggesting limited correlation between royalties across municipalities. Together with the finding that oil and gas revenues impose a negative spillover effect on the night-time light emissions of non-oil 
municipalities, this finding shows that the small royalties that are paid to non-oil municipalities do not compensate other mechanisms that affect them negatively.

In Column 2, we examine the impact of oil revenues on population and find that they significantly increase the population of oil municipalities but have no statistically significant impact on neighboring municipalities. A 10 percent increase in oil and gas revenues leads to 0.1 percent increase in the size of the population in oil municipalities but there we find no evidence of a drain of workers in neighboring municipalities. Movements of population from non-oil municipalities to oil-producing municipalities are therefore not the channel of transmission of the spillovers from oil and gas revenues. The increase in population therefore likely originates in non-neighboring municipalities.

In Columns 3 to 6, we test a specific prediction of the theoretical models developed by Moretti (2011) and Allcott and Keniston (2015). They argue that the rise in labor demand following resource booms will increase wages in resource-related sectors. To examine that, we rely on data on wages gathered by Registro Anual de Informaes Sociais (RAIS), an official micro database for all registered formal workers during the period 2002-2013. The wages are expressed in real terms, with nominal figures deflated by CPI index provided by IPEA (Índice Nacional de Preços ao Consumidor - INPC) and transformed to US dollars. Besides looking at overall wages, we also explore heterogeneous effects by sector, namely the tradable sector, defined as the sum of the manufacturing and agriculture sectors, and non-tradeable sectors, defined as the service sector.

Column 3 uses the average wage in all sectors as dependent variable. In that column, the coefficients of oil and gas revenues is positive, meaning that wages in oil producing municipalities are statistically significantly increasing with oil and gas revenues. The spatial lag of the independent variable exhibits a negative but statistically insignificant coefficient, suggesting that there are no systematic spillovers for oil and gas revenues on wages in general.

In neighboring municipalities, wages are adversely affected by oil revenues and the impact is particularly strong-both in magnitude and statistical significance- for the service sector. The coefficient for the direct effects indicates that a 10 percent increase in oil revenues increases manufacturing and service wages in oil producing municipalities by 6.6, 9.2 and 25.7 US dollars, respectively, while agriculture sector's wages are left unaffected. In contrast, manufacturing, agriculture and service wages in neighboring municipalities significantly decline by 7.4, 12.6, and 102 US dollars for each 10 percent increase in oil revenues. The total effect of oil revenues on wages is positive, but statistically insignificant for overall and manufacturing wages, meaning that the uptick in wages witnessed by oil municipalities is compensated by a decline in wages in neighboring municipalities. For the service and agriculture sectors, the coefficient of the indirect effect is greater in size than the coefficient of the direct effect, so that the total effect is negative and statistically significant.

In Column 6, we examine the effect of oil and gas revenues on local prices. Following the reported increase in sectoral wages, we would expect a rise in the demand for locally traded goods, which in turn increase their prices. Following Aragon and Rud (2013), we test this proposition using the 
prices of locally produced agriculture goods. Local prices are based on the Municipal Agricultural Production survey (Produção Agrícola Municipal), obtained from IPEA for the period 1992-2010 and expressed in US dollars real terms. To determine the main agriculture crop for each municipality and its price, we follow Berman et al. (2017) and define it as the one with the highest total production value over the entire period (evaluated at 2000 prices). We then divide the production value of the main crop by production (measured in tons) to get the local crop price per ton. As expected, local prices in oil municipalities increase with oil revenues, whereas they decline in neighboring municipalities. A 10 percent rise in oil and gas revenues increases local prices by 2 dollars per ton, while it reduces them in neighboring municipalities by almost the same amount.

Finally, in Column 7, we analyze the impact of oil and gas revenues on crime. Crime rates are measured by the number of homicides per 100,000 inhabitants in a given year and obtained from IPEA during the period 1992-2013. ${ }^{21}$ Previous studies identify two opposite effects of natural resources on criminal activities (see for example Dube and Vargass, 2013). On the one hand, increased royalties increase incomes, hence the incentives to engage in theft, expropriation, and illegal activities in general. This effect is referred to as the rapacity effect. On the other hand, a deteriorating economic situation reduces the opportunity costs of committing crimes and can thus lead to a surge in crime. In Column 7, both oil and gas revenues and their spatial lag exhibit a positive coefficient. Although the coefficient of the spatial lag of oil and gas revenues is statistically insignificant at conventional levels, their marginal effect reported in the bottom panel of the table is statistically significant at the ten-percent level. Accordingly, an increase in oil and gas revenues increases crime in both oil municipalities and neighboring municipalities, suggesting that crime is one of the spillovers of oil and gas revenues. This is reminiscent of Caselli and Michaels (2013) who find that oil windfalls in Brazil increase the incidence of illegal activities by local politicians.

Overall, the results suggest that oil revenues exhibit positive and negative effects, where the balance between both effects depends on the proximity to oil municipalities. In oil municipalities, the positive effects of oil revenues on royalties, wages, local prices and population suppress the effect of negative externalities found in the proliferation of criminal activities. As result, we see a positive effect on the overall economic activity. In neighboring municipalities, the severe decline in wages and local prices is amplified by the increase in crime rates and hence, we see a negative effect in the overall economic activity.

\footnotetext{
${ }^{21}$ Homicides rates is a good proxy for crime rates given that lack of data on other forms of non-violent crimes (i.e. property crimes such as theft, robbery and burglary) at the municipal level. The same measure was used by DixCarneiro et al. (2018) in estimating the impact of trade shocks on crime rates. We refer to their paper for more discussion on the high correlation between homicides rates and other types of crime at the state level.
} 


\section{Conclusion}

We study the spatial distribution of the effect of oil and gas revenues on Brazilian municipalities. Using variations in the international prices of oil and gas to establish causality, we find that oil and gas revenues increase economic activity in oil-producing municipalities. However, we also observe that oil and gas revenues in a municipality impose a negative spill-over on neighboring municipalities. Both gas and oil revenues contribute to those effects. Moreover, our main finding is not driven by outliers or sample selection and survives various specifications allowing for a dynamic relationship. A placebo test shows that it is not spurious.

The finding that oil and gas revenues benefit oil-producing municipalities is in line with the within-country literature that emphasizes that areas endowed with natural resources tend to benefit from it. In that respect, it shows that oil-producing municipalities do not suffer from a resource curse. However, neighboring municipalities do. Accordingly, oil-producing municipalities impose a negative spillover on their neighbors. We observe that those spillovers become larger relative to direct effects the further from oil production a municipality is located and dominate in municipalities located beyond 150 km from oil activities.

When studying how oil and gas revenues affect non-oil municipalities, we confirm that oil and gas revenues increase royalties in neighboring municipalities. They also increase population, real wages, in particular in the manufacturing sector and in agriculture and services, as well as local real prices and crime. Moreover, we observe negative spillovers of oil and gas revenues to wages and prices and positive spillovers on crime in neighboring municipalities.

A consequence of finding negative spillovers of oil and gas revenues on non-oil municipalities is that the sum of direct and spillover effects is close to zero. Accordingly, we can observe no effect of oil and gas revenues on economic activity at higher levels of aggregation, as direct and spillover effects cancel out. This finding may explain the conflicting results of the cross-country literature. In any case, they point out to the distributive effects of natural resources. Our results uncover the geographic dimension of those distributive effects. We also find that oil revenues affect wages and prices, which hints at possible distributive effects between factors of production. They warrant future research.

\section{References}

Agencia Nacional de Petroleo (ANP) (2019). Available at: http://www.anp.gov.br/.

Alexeev, M., and Conrad, R. (2009). The elusive curse of oil. Review of Economicsand Statistics, 91(3), 586-598.

Allcott, H., and Keniston, D. (2018). Dutch disease or agglomeration? The local economic effects of natural resource booms in modern America. Review of Economic Studies, 85(2), 695-731.

Aragón, F. and Rud, J. (2013). Natural Resources and local communities: Evidence from a Peruvian gold mine. American Economic Journal: Economic Policy, 5(2), pp.1-25.

Auty, R. (2001). The political economy of resource-driven growth. European Economic Review, 45(46), pp.839-846. 
Black, D., McKinnish, T., and Sanders, S. (2005). The economic impact of the coal boom and bust. The Economic Journal, 115(503), 449-476.

Caselli, F. and Michaels, G. (2013). Do oil windfalls improve living standards? Evidence from Brazil. American Economic Journal: Applied Economics, 5(1), pp.208-238.

Collier, P. (2000). Ethnicity, politics and economic performance. Economics and Politics, 12(3), pp.225245.

Collier, P. and Hoeffler, A. (2005). Resource rents, governance, and conflict. Journal of Conflict Resolution, 49(4), pp.625-633.

Cotet, A. and Tsui, K. (2013). Oil and conflict: What does the cross country evidence really show?. American Economic Journal: Macroeconomics, 5(1), pp.49-80.

Dell, M. (2010). The persistent effects of Peru's mining mita. Econometrica, 78(6), pp.1863-1903.The persistent effects of Peru's mining mita. SSRN Electronic Journal.

Doll, C., Muller, J. and Morley, J. (2006). Mapping regional economic activity from night-time light satellite imagery. Ecological Economics, 57(1), pp.75-92.

Gradstein, M., and Klemp, M. (2016). Can black gold shine? The effect of oil prices on nighttime light in Brazil.

Henderson, J., Storeygard, A. and Weil, D. (2012). Measuring economic growth from outer space. American Economic Review, 102(2), pp.994-1028.

Hodler, R. (2006). The curse of natural resources in fractionalized countries. European Economic Review, 50(6), pp.1367-1386.

Hodler, R., and Raschky, P. A. (2014). Regional favoritism. Quarterly Journal of Economics, 129(2), pp. 995-1033.

Instituto Brasileiro de Geografia e Estatística (IBGE) (2019). Available at: https://ww2.ibge.gov.br/english/.

IPEA. (2019). Available at: http://www.ipea.gov.br/portal/index.php?option=com_content\&Itemid=61

Isham, J. (2005). The varieties of resource experience: Natural resource export structures and the political economy of economic growth. World Bank Economic Review, 19(2), pp.141-174.

Keola, S., Andersson, M. and Hall, O. (2015). Monitoring economic development from space: Using nighttime light and land cover data to measure economic growth. World Development, 66, pp.322-334.

Kotsadam, A. and Tolonen, A. (2016). African mining, gender, and local employment. World Development, 83, pp.325-339.

Lei, Y. and Michaels, G. (2014). Do giant oilfield discoveries fuel internal armed conflicts? Journal of Development Economics, 110, pp.139-157.

Mamo, N., Bhattacharyya, S. and Moradi, A. (2019). Intensive and extensive margins of mining and development: Evidence from Sub-Saharan Africa. Journal of Development Economics, 139, pp.28-49.

Mehlum, H., Moene, K., and Torvik, R. (2006). Institutions and the resource curse. Economic Joumal, 116(508), pp.1-20.

Michaels, G. (2011). The long term consequences of resource-based specialization. Economic Journal, 121(551), pp.31-57.

Michalopoulos, S. and Papaioannou, E. (2013). National institutions and subnational development in Africa . Quarterly Journal of Economics, 129(1), pp.151-213. 
Monteiro, J., and Ferraz, C. (2010). Does Oil Make Leaders Unaccountable? Evidence from Brazil's offshore boom, PUC-Rio mimeo.

National Oceanic and Atmospheric Administration (NOAA) (2014). DMSP-OLS Nighttime Lights Time Series 1992-2013 (Version 4), Available at: https://ngdc.noaa.gov/eog/dmsp/downloadV4composites.html.

Robinson, J., Torvik, R., and Verdier, T. (2006). Political foundations of the resource curse. Journal of Development Economics, 79(2), pp.447-468.

Sachs, J. and Warner, A. (1995). Economic Convergence and Economic Policies. SSRN Electronic Journal.

Sachs, J. and Warner, A. (2001). The curse of natural resources. European Economic Review, 45(4-6), pp.827-838.

Tornell, A. and Lane, P. (1999). The voracity effect. American Economic Review, 89(1), pp.22-46.

Torvik, R. (2002). Natural resources, rent seeking and welfare. Joumal of Development Economics, 67(2), pp.455-470. 


\section{Appendix A}

Our data on oil and gas production come from Brazilian Agencia Nacional de Petroleo (ANP), which publishes data on oil and gas production and reference prices by oil field on a monthly basis. The data is extracted from the exploration and production of oil and gas database(Banco de Dados de Exploração e produção de óleo e gás - BDEP). The reference price is the maximum between the actual sale price of the oil extracted in a particular field and an imputed sale price based on prevailing world-market prices for oil with similar chemical composition. These prices are only available from 1999 onward, which is the reason why we use international oil prices, taken from International Financial Statistics (IFS), to allow us to have a longer time series and to match the available data on night-lights. Given that, we calculate the monthly production value for each oil field from 1992 based on the following formula: oil production in $1992 \times$ international oil price + gas production in $1992 \times$ international gas price. The value of annual output is then the sum of the year of the monthly output values.

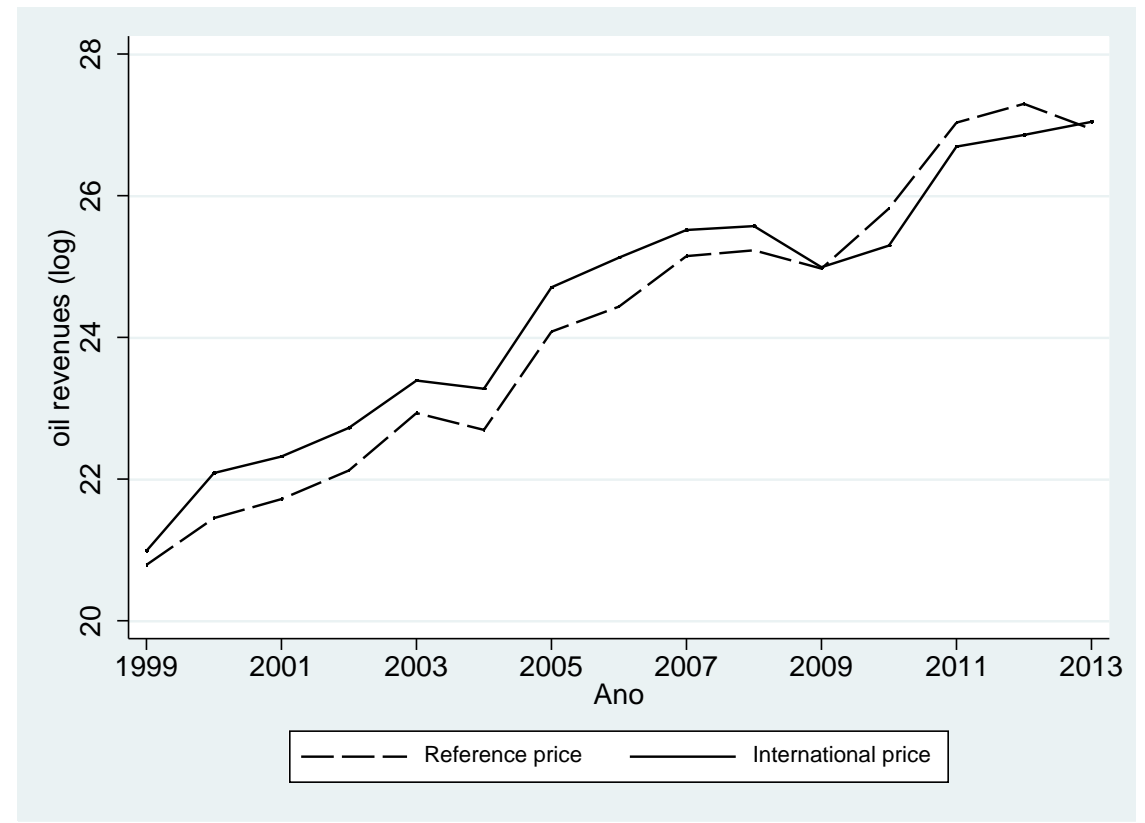

Figure A1: Oil revenues (in Brazilian Real) calculated by Brazilian reference price (dashed line) and international oil prices (solid line)

Next, we assign these output values to municipalities based on two approaches. The first approach allocates offshore oil values to municipalities using the Percentuais Médios de Confrontação for December 2013, which lists the assigned quotas for municipalities facing offshore oil fields. These quotas show little variation over time, and our results are robust to using quotas from different month, namely July 2007. The second approach assigns onshore oil fields to municipalities. To do that, we first georeferenced onshore fields (that were in production phase in October 2018) using GIS information disclosed by ANP’s BDEP database. If oil field is located 
within the boundaries of only one municipality, its output is fully assigned to this particular municipality. If, on the other hand, an oil field is located over a number of municipalities' boundaries, we divide the oil production based on the percentage of the occupied area by the oil field in each municipality.

To check we calculation, we compared municipal oil revenues obtained using Brazilian reference prices (in Brazilian Real) with the one we constructed using international oil prices. For the latter series, we converted the values from US dollars to Brazilian Real. Figure A1 plots the evolution of oil revenues from the two series. For the period 1999-2013, the two series were almost the same with the degree of correlation reaching 0.9986 . 


\section{Appendix B}

Table B1: Further robustness checks

Panel A: Estimated Coefficients $\ln ($ Revenues)

$W(\ln ($ Revenues))

$\ln$ (Revenues), $\mathrm{t}-2$

$W(\ln ($ Revenues) $), \mathrm{t}-2$

W(light)

Exposure $<=100$

Exposure $<=200$

Exposure $<=300$

Exposure $>300$

Number of observations

Number of municipalities

R-squared

InPopulation

Municipality FE

Year FE

Panel B: Direct and Indirect effects from SDM

Direct Effect

Indirect effect

Total effect

\begin{tabular}{ccr}
$(\mathbf{1})$ & $(\mathbf{2})$ & $\mathbf{( 3 )}$ \\
\hline Light & Light & Light \\
\hline SDM & SDM & SDM \\
\hline $\begin{array}{c}\text { Drop lights }>\text { 99th } \\
\text { percentile }\end{array}$ & Drop capital cities & $\begin{array}{c}\text { Lagged } \\
\text { revenu }\end{array}$ \\
\hline $0.762^{* * *}$ & & \\
$(0.205)$ & $0.682^{* * *}$ & \\
$-0.957^{* * *}$ & $(0.212)$ & \\
$(0.278)$ & $-0.812^{* *}$ & \\
& $(0.357)$ & $0.842^{* *}$ \\
& & $(0.215)$ \\
& & $-0.734^{*}$ \\
$0.212^{* * *}$ & & $(0.370$ \\
$(0.018)$ & $0.169^{* * *}$ & $0.174^{* * *}$ \\
& $(0.018)$ & $(0.018)$
\end{tabular}

Dependent variable is mean night-time light intensity. The sample is restricted to municipalities located in 9 hydrocarbons-producing states. All columns shows the estimates of a spatial Durbin model (SDM) employing a row standardized contiguity matrix. Estimates are based on a spatial weights contiguity matrix W that assigns 1 to municipalities that share a common border. Panel B reports estimates of direct, indirect and total effects from SDM, with standard errors computed by Monte Carlo standard errors using 100 replications (Lesage and Pace, 2009). Robust standard errors reported in parentheses and clustered at the municipal level. Significantly different from zero at * $10 \%$ significance, **5\% significance, ***1\% significance. 